\title{
Performing Students' Virtue through Green Constitution
}

\author{
Susan Fitriasari, Dasim Budimansyah*, Sapriya Sapriya, Rahmat Rahmat \\ Civic Education \\ Universitas Pendidikan Indonesia \\ Bandung, Indonesia \\ *budimansyah@upi.edu
}

\begin{abstract}
The plenteous natural resources have not been balanced with the optimization of human resources in preserving nature and displaying the attitude of responsibility towards nature and its environment. Every individual often disregard environmental laws and policies with an environmentally destructive attitude in improve constitutional awareness for the young generation. Through Civic Education based Green Constitution, students' civility towards the environment will be created, among others, developing the value of caring, self-control, self-assertiveness, and self-reliance. This study aims to describe Civic Education based Green Constitution learning model which is integrated into the learning activities in the classroom. Research and development implemented in Vocational High School 1 SukalarangSukabumi. The results showed that 1) Civic Education based Green Constitution learning model was designed based on the whole of learning component covering material, method, media, source, and evaluation. The characteristic of this model was developed through the adoption of Project Citizen with the key issues about environmental issues of water exploitation; 2) The implementation of Civic Education based Green Constitution learning systematically described from the initial activities, the core activities to the closing activities and the students' virtue on the environment are implicitly incorporated; 3) Based on testing of two different classes in each school, the increase of students' virtue in the control class included in the low category and in the experimental class included in the medium category. Therefore, the improvement of the experimental class is higher than the control class. However, the development of industrialization is very influential to the environmental conservation, therefore how far the Green Constitution put environmental norms into the state constitution.
\end{abstract}

Keywords- green constitution, civic virtue, learning model, civic education, student

\section{INTRODUCTION}

In the $21^{\text {st }}$ century, environmental conditions are an important issue all over the world. The population is increasing, the technological advances that make people burdened and require the expansion of the use of natural resources. There is substantial evidence to suggest that such development has caused adverse effects on the environment. Looking at the above, attention to environmental degradation is not only in our country, but is the focus of the global community, so that the global community is required to be more responsible for addressing environmental issues [1]. The concept of Green Constitution has been widely known in many countries although with different forms and names of activities, but still has a mission on Green Constitution.

Green Constitution movement can be done starting from family environment, school and society. In this research, the Green Constitution movement is done by revitalizing the learning of Civic Education based Green Constitution. At the level of schooling material about the constitution and various other legal rules contained in the learning of Civic Education. In Indonesia, Civic Education carries a state education based on the Constitution of the State Republic Indonesia 1945 or a constitution that implicitly contains teaching on how citizens in exercising their rights and obligations in accordance with existing regulations. In this case, there is no longer any reason for legal ignorance should it be clear that the individual or company must gain awareness and understanding of the requirements of the Environmental Act. Once the necessary knowledge is obtained, the implementation of the law must be monitored constantly. There is time and financial costs for the educational process [2].

In addition, Civic Education as an educational science study that focuses on the development of intelligent, democratic, and religious citizens and has multi-dimensional characteristics, needs to be seen in three demographics. First, Citizenship Education as a study of "Civic Virtue" and "Civic Culture" which is the foundation of Civic Education as a curricular program and socio-cultural civic movement. Second, Civic Education as a curricular program has a vision and mission of developing intelligent, democratic, and religious citizens in both educational backgrounds both at school and outside the school, which serves as the basis of the overall orientation of academic efforts to understand phenomena and social problems in an interdisciplinary manner, so that students can make clear and meaningful and beneficial decisions as much as possible for individuals, communities, nations and 
countries. Third, Civic Education as a synergistic citizenship social-cultural movement is undertaken in an effort to build "Civic Virtue" and "Civic Culture" through active participatory intelligently, democracy and religious in their environment [3].

Civic Education by Cogan in Winataputra and Budimansyah generally refers to "... the kind of course work taking place within the context of the formalized schooling structure" [4]. The point is the type of job training with a formal school context. In this position Civic Education is treated as ".. the foundational course of work in school designed to prepare ... young citizens for an active role in their community in their adult lives". The above statement implies that Civic Education is a basic subject designed to prepare citizen youth to be able to play an active role in society, later on as adults.

In relation to this the concepts of Green Constitution are contained in the material of Civic Education. In the process of Civic Education learning contains a complex activity so not only transfer of knowledge from educators to students in a textual way but should relate to how the learning is organized contextually. Every learning process, should be strived to deliver learners on the mastery of the competence of attitudes and values so that the process of direct experience can make students become mature individuals in the face of real situations in the environment. Therefore, the learning process should use the relevant learning model. One of the most suitable learning models used in Civic Education learning based Green Constitution is integrated with Project Citizen for the development of "Civic Knowledge, Civic Dispositions, Civic Skills, Civic Confidence, Civic Commitment, Civic Competence which leads to the development of well-informed, reasoned, and responsible decision making (the ability to make informed, reasoned, and responsible decisions)" [5].

The abundant natural resources have not been balanced with the optimization of human resources in preserving nature and displaying the attitude of responsibility towards nature and its environment. Arising damage to nature both on land, sea and air is the act of the man himself. The ultimate cause should be controlled by the educational process that can suppress the attitude of environmental damage, so that the process of mindset formation, attitudes and actions can occur to internalize into each individual. Based on this fact, Civic Education has a strategic role in raising awareness of civilization of young citizens. This is because one of the missions of Civic Education is as legal education, which is to foster students to understand their rights and obligations as citizens, including to understand the constitution. In this study, Green Constitution is done in school by revitalizing the learning of Civic Education based Green Constitution to cultivate Civic Virtue toward the environment.

\section{RESEARCH METHOD}

The approach used in this research is mixed method, that is quantitative and qualitative approach. with the pattern of "the dominant-less dominant design" [6]. Quantitative approach is used as the dominant approach in this study rather than qualitative approach. This is because the purpose of this study is to measure the relationship variable, test the hypothesis, and make the proposition and the conclusion of a phenomenon.

This quantitative and qualitative approach is made a foothold in research and development ( $R$ \& D) or Educational Research and Development and also called Research Based Development. Borg and Gall [7], explained that "Educational Research and Development is a process used to develop and validate educational products". Research and development is a process or steps to develop a new product or refine an existing product. Research development (Development and Development) implemented in Vocational High School 1 Sukalarang-Sukabumi using control class and experiment class as quasi experiment research.

The flow of research begins with a preliminary study of school curriculum and Civic Education learning in high school and which is used as a source in the preparation of instruments in the form of observation. The next stage formulates the problem and research objectives that are used to direct the research needs. A study of literature related to the Civic Education based Green Constitution learning model and Civic Virtue. Next compile learning tools and instruments such as questionnaires. Questionnaires were then validated with trials to analyze difficulty, differentiation, and reliability of tests. After that a revision of the questionnaire is not yet feasible to be used as research instrument.

The implementation of Green Constitution's Cn-based learning is done on two predetermined classes. This stage begins with the implementation of the Green Constitutionbased Cnc model. Furthermore, students are asked to fill out a questionnaire and interviewed some students to know the interest, motivation and student responses to the model applied in the learning. The last step is to analyze the data and findings obtained in the form of data to prepare the report.

\section{RESEARCH RESULT}

The results showed that 1) The learning model of Civic Education based Green Constitution was designed based on the whole learning component covering material, method, media, source, and evaluation. The characteristic of this model was developed through the adoption of Project Citizen with the main issue raised as the environmental issue of water exploitation.

\section{A. The Planning of Civic Education based Green Constitution Learning}

The planning Civic Education based Green Constitution learning in all components of learning in schools are described as follows:

\section{1) Learning Material}

The material developed based on Green Constitution learning model is adjusted based on Core Competence (KI) and Basic Competency (KD) of class XI curriculum 2013 odd semester of academic year 2016-2017. The material is selected based on the suitability of this study. Implementation of materials submitted on the basis of basic competence 2.3 Practice the values contained in the articles of the Constitution of the Republic Indonesia 1945 in various aspects of life 
(ipoleksisbudhankam and law), 3.5 Analyze the practice of protection and law enforcement within the community to ensure justice and peace, 4.5 Present the results of analysis of safeguard and law enforcement practices to ensure justice and peace in the life of society, nation and state.

Specifically these basic competencies are in the fifth chapter of the eleventh grade with the theme "Protection and Law Enforcement". Sub-material covered include; legal understanding, law enforcement, judiciary, criminal and civil proceedings, display disciplinary behavior, respect law enforcement. This material is very relevant to the learning model that is used learning based Green Constitution. Material delivered based on Core Competence and Basic Competence on protection and law enforcement. The material consistency in $\mathrm{KI} / \mathrm{KD}$ curriculum 2013 deals with the spiritual attitudes, social attitudes, knowledge and skills that contain not only the subject matter covered in the syllabus but inserting the values of civic virtue into the material.

If illustrated, there is a network of Civic Education based Green Constitution learning systems that contains the curriculum sphere of 2013.

Curriculum 2013 Integration in Civic Material.

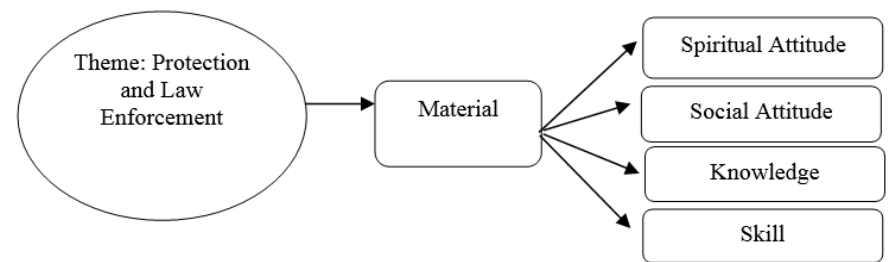

Fig. 1. Network Integration of Curriculum 2013 Competency Source: (Processed researcher, 2017)

From the network of curriculum 2013 competence system above students emphasized on the standards of graduate students. Given the Civic Education subjects use a multidisciplinary approach that covers several disciplines, such as values, moral, and norm education in addition to character, constitutional, political, and legal education. Academically, this sorting is necessary for the purposes of analysis, but in practice it is intended in the learning process to show that all dimensions are basically integrated and difficult to separate.

\section{2) Learning Method}

Approach and learning strategy used in the Civic Education based Green Constitution learning model through the integration of Contextual teaching and learning and value learning. The learning methods used in this learning model include various lectures, Focus Group Discussion, VCT (Value Clarification Technique), and Project Citizen. The further explanations include the following:

\section{a) Varied Lectures}

Explanation of introductory material done by educator/teacher with lecture method and question and answer about the material being discussed. The form of the lecture is designed with interactive media collaboration so that students focus on the teacher. The material in this lesson is no less associated with the local socio-cultural environment by taking advantage of local wisdom that developed in the area.

\section{b) Focus Group Disscusion}

After a material or lecture explanation, the teacher coordinates the student to perform Focus Group Disscusion. Classes are divided into 4 groups in which members of each group are 9-10 people. Each group has issues to be discussed.

\section{c) VCT (Value Clarification Technique)}

Value learning in the form of value clarification technique (VCT) through image analysis, photography, illustration, story analysis, and film analysis, and VCT Lists. VCT is done at the end of the lesson in which learners / students take the meaning of each learning activity.

\section{d) Jigsaw}

A learning model in which students in groups must master the material to be communicated to the other group's friends. The topic distribution is determined by the teacher.

\section{e) Project Citizen}

The citizenship-based learning model aims to motivate and empower learners in using democratic citizenship rights and responsibilities through intensive research on public policy issues in schools or in communities

\section{3) Media and Resources}

Media and learning resources of Civic Education based Green Constitution learning model used in this research based on multimedia which include media, picture, photo, illustration, cardboard as show case material, and others. The materials used for making the show case in the form of media use as needed. Learning resources used include teaching materials/books Class XI Civics Education and Student Worksheet.

\section{4) Assessment}

One of the Civic Education based Green Constitution learning model characteristics is by using an authentic assessment (Authentic Assessment). Authentic assessment used in this study include:

\section{a) Show Case Assessment}

The show case assessment is the peak of the assessment conducted on the use of Green Constitution learning model. This assessment includes a series of presentations as accountability in which the previous research was conducted. This assessment focuses on the presentation aspect of each group. This assessment includes: the ability of each group presentation, judgment of yells, the ability to answer questions given by the jury.

\section{b) Product Assessment}

Product assessment is an assessment given to the work contained in Project Citizen's portfolio. This assessment includes; obedience to the rules required in making this research, aesthetic value in portfolio, neatness. 


\section{c) Attitude Assessment}

This assessment focuses on the attitude aspects during the learning process is designed to resolve learning activities (beginning to end).

\section{d) Self Assessment}

This assessment is an assessment done by each group against himself which is done proportionally and honestly.

\section{B. The Implementastion of Civic Education based Green Constitution learning}

The implementation of Civic Education based Green Constitution systematically illustrated from the initial activity, the core activities to the closing activities and the students' virtue toward the environment are implicitly incorporated. The process of teaching and learning activities is done based on the learning process of $\mathrm{Cn}$ based on Green Constitution with different characteristic with Project Citizen model in general. In the process of Civic Education based Green Constitution learning contains collaborative learning methods that are comprehensively designed through the formulation of materials, methods, media, sources and evaluation. The implementation of Civic Education based Green Constitution learning activities conducted at Vocational High School 1 Sukalarang-Sukabumi with environmental problems about water exploitation. The following are the stages of the learning process which includes preliminary activities, core activities, and closing activities in four meetings.

TABLE I. Civic Education Based Green Constitution LEARning ACtivities

\begin{tabular}{|c|c|}
\hline Activity & Description \\
\hline Introduction & $\begin{array}{l}\text { a. Teacher prepares class in learning (class cleanliness, prayer and absenteeism). } \\
\text { b. Teacher explore the students readiness to follow learning materials to be taught. Teacher gives appreciation for the students' answer. } \\
\text { c. Teacher shows a video about legal issues and explains communicatively the content of the video. } \\
\text { d. Teacher gives information about competence to be achieved. }\end{array}$ \\
\hline Core & 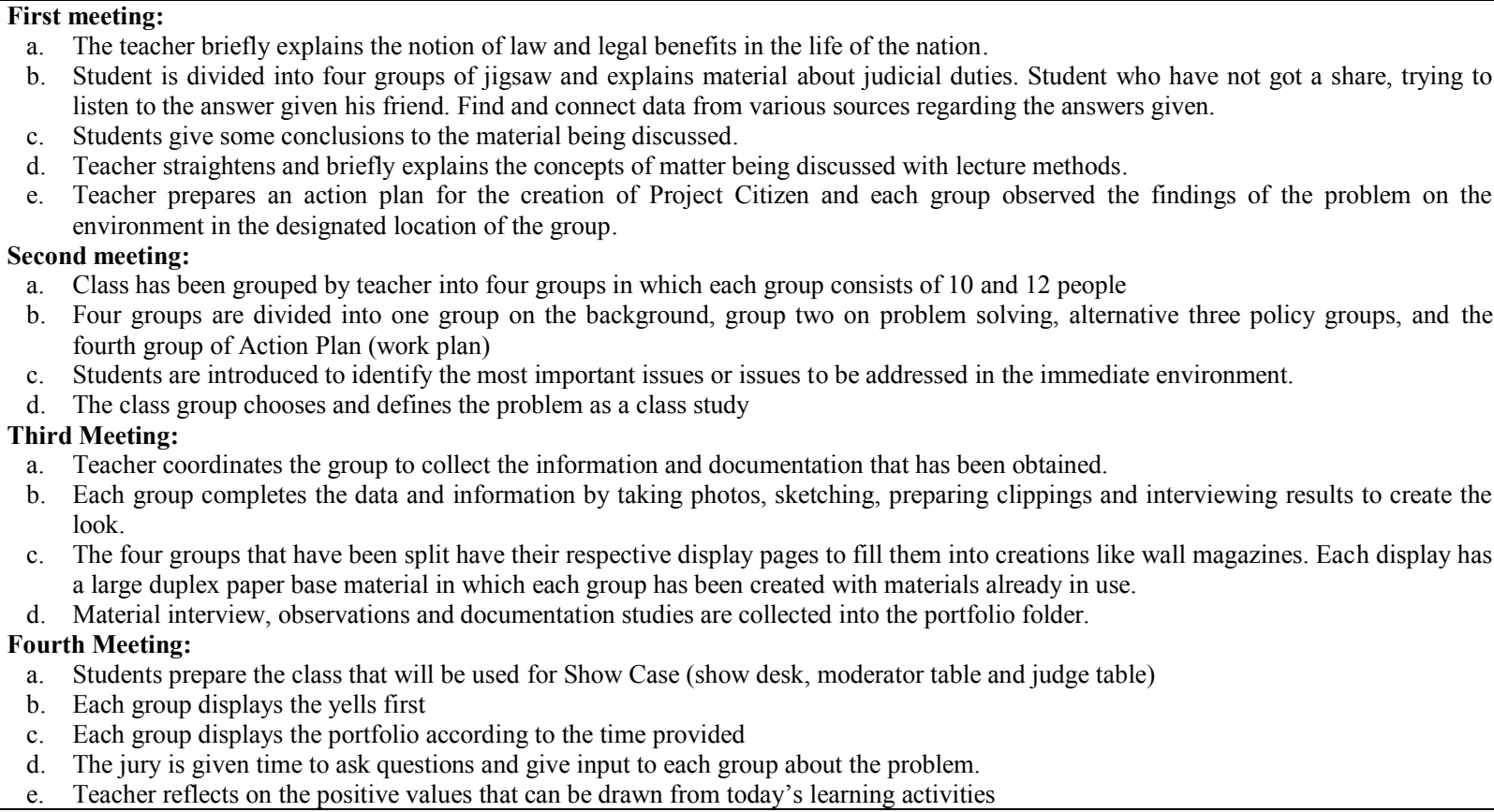 \\
\hline Closing & $\begin{array}{l}\text { a. Teacher closes the lesson by reviewing the subject matter as well as the individual activities and group activities. } \\
\text { b. Teacher can ask if the student has understood the material. } \\
\text { c. Teacher asks the students to prepare for evaluation and test. }\end{array}$ \\
\hline
\end{tabular}

\section{The Increas of Students' Virtue toward the Environment}

Based on testing of two different classes at Vocational High School 1 Sukalarang-Sukabumi, the increase of students' virtue in the control class included in the low category and in the experimental class included in the medium category. Therefore, the improvement of the experimental class is higher than the control class. But in fact the development of industrialization is very influential on saving the environment, therefore how far the Green Constitution put environmental norms into the constitution of the state.
Testing this hypothesis using the independent samples $t$ test, to find out the final results of the experimental class and the control class based on the gain value. The hypothesis tested is as follows:

Ha : $Y_{\text {post }}=Y_{\text {pre }}$ that there is a significant difference to the increase of civic virtue using the Civic Education based Green Constitution learning is higher than the class using conventional learning on the measurement of gain value.

$H_{0}: Y_{\text {post }}=Y_{\text {pre }}$ that there is no significant difference to the increase of civic virtue using Civic Education based Green Constitution learning 
is higher than the class using conventional learning on the measurement of gain value.

Criterion $\mathrm{H} 0$ is rejected if Sig (2-tailed) $<\mathrm{a}(0.05)$

The results of statistical calculations with the help of SPSS 20 software can be seen in the table below:

TABLE II. TEST RESUlT OF HyPOTHESIS GAIN VALUE IN EXPERIMENT Class AND CONTROL ClASS

\begin{tabular}{|c|l|c|c|c|c|}
\hline & \multicolumn{1}{|c|}{ Class } & N & Mean & $\begin{array}{c}\text { Std. } \\
\text { Deviation }\end{array}$ & $\begin{array}{c}\text { Std. Error } \\
\text { Mean }\end{array}$ \\
\hline \multirow{2}{*}{ N Gain } & Control & 159 & .1223 & .07091 & .00562 \\
\cline { 2 - 6 } & Experiment & 155 & .5688 & .09575 & .00769 \\
\hline
\end{tabular}

Based on the table above that the value of Sig. (2-tailed) of $0.000<\mathrm{a}(0.05)$, then $\mathrm{H} 0$ is rejected, which means there is a significant difference to the increase of civic virtue in the classroom using the Civic Education based Green Constitution learning is higher than the class using the conventional learning model on the measurement of value gain.

\section{DISCUSSION}

The learning of Civic Education based on Green Constitution developed in High School is the implementation of learning by involving Green Constitution concept. The term of Green Constitution focuses on legal protection of the environment. The material of Green Constitution is very relevant to be learned in Civic Education subject at school especially high school. This is because to see the current condition about the rampant destruction of nature, the environment in Indonesia becomes a serious concern for the life of nation and state in Indonesia. Through Civic Education subjects in schools, can be used as a tool to create a generation of Indonesia who care about awareness of the environment [8].

This mission is always carried by Civic Education in school in transforming the importance of legal awareness to the environment. The legal basis of the Green Constitution is stipulated in the Constitution of the Republic Indonesia 1945 The 4th Amendment has mandated the preservation of the environment. This can be seen in the elaboration of the Constitution of the State Republic of Indonesia 1945 Article 33 paragraph (4) reads "The national economy is organized based on economic democracy with the principle of togetherness, efficiency-fair, sustainable, environmentally-oriented, selfreliance, and by balancing progress and national economic unity". This is clarified by the birth of Act No. 32 of 2009 on Environmental Protection and Management (UUPPLH).

Based on the empirical findings that demonstrate the application of Civic Education based Green Constitution learning in schooling to be an effective and fun learning towards the development of civic virtue, it produces some of the following information.

First, the process of Civic Education learning is a process of student learning activities are engineered by all components of learning that includes teachers, materials, methods, media, learning resources and evaluation of learning [9]. Therefore, in the Civic Education based Green Constitution learning process, teachers should organize materials, methods, media, learning resources and evaluation of learning as an important component in learning to take place effective learning process so as to achieve learning objectives. The purpose of learning is not only focused on one aspect of cognitive but affective aspects and psychomotor aspects should be instilled in students and behaviors that must be displayed by students after carrying out learning activities [10]. The formulation of the learning objectives in the development of the Civic Education based Green Constitution learning model is based on the theory of measurement on Bloom's taxonomy and Anderson's taxonomy in which not only develop cognitive, affective and psychomotor skills but the form or way of thinking of students is done in an active process [11].

The material developed in the implementation of the Civic Education based Green Constitution learning model is developed from the material importance of the law to life, the function of each judiciary in Indonesia, the principles of criminal and civil law in Indonesia and display a law-abiding attitude. The content of legal awareness material which contains how the legal awareness in protecting the environment will contribute to the growth of citizens' awareness in taking action and movement in protecting their environment. This is reinforced by Turner's interpretation of ecological citizenship as an expression of the right to protect the natural environment, so that the form of ecological citizenship is rooted and derived from the desire to participate emotionally and spiritually with the environment $[12,13]$.

The method used to adjust to the existing material on the Basic Competency that has been determined include: 1) Video Values Clarification Technique (VCT); 2) Jigsaw; 3) Make a Match, and 4) Project Citizen. Civic Education based on Green Constitution learning with such methods will make students to be creative. This is because the design of this learning supports them to be creative, have a product and contribute real in positioning student part of this country. In this case Ridwan suggests two types of knowledge necessary to produce creativity, namely [14]: 1) profound experience and focus on a particular study that makes a person an expert; 2) the ability to combine elements in new ways. Learning is rich in experience because they not only learn in the classroom, but they also learn outside the classroom, the environment and the place that supports them. Students attempt to combine the knowledge and experience they have with others who are more expert even someone who comes from across disciplines.

Learning resources used, among others: 1) Human, the main component in this learning activity, among others; teachers, communities, experts (interviews conducted by students in digging information), and stakeholder officials; 2) Books/Libraries, an essential component book in Green Constitution learning activities, in addition to Cyber Package books, encyclopaedias, laws and environmental books; 3) Mass Media, the use of teaching materials in the printed and online media (internet) is very effective in teaching and learning activities, the use of sources of newspapers and news sites available on the internet students as an additional media required especially in the search for information in preparing the project citizen in the portfolio; 4) Environment, students use the environment as one source of learning. Students go directly to see problems about environmental damage to the environment they find directly. The use of such a rich source of 
learning makes students have a lot of experience generated when the learning process is done, a number of people involved for real information. It makes students will have the creativity in themselves that they get from the learning process done.

Media is a component of a learning resource or physical vehicle that contains instructional material in a student environment that can help students to learn. The media used in the implementation of the model of learning $\mathrm{Cn}$ based on the green constitution are: 1) White board, markers; used as usual in the learning process to write important things on the board; 2) Infocus, laptop \& speakers active; this medium is used in displaying power points and viewing of learning videos such as video exploitation of water; 3) Duplex paper, stationery; as a portfolio material that is presented and become one component of the assessment. Use of the media is very helpful implementation of teaching and learning activities that have been planned teachers to achieve the desired learning objectives. This can be seen from the function of the media that is (1) overcome the limited experience possessed by the learners; (2) goes beyond classroom boundaries; (3) enabling direct interaction between learners and their environment; (4) produce uniform observations; (5) embed the basic concepts that are true, concrete, and realistic; (6) generate new desires and interests; (7) generate motivation and stimulate children to learn; (8) provides an integral / comprehensive experience from the concrete to the abstract [15].

Furthermore, the authentic assessment used to assess the Civic Education based Green Constitution learning model includes: 1) Assessment of attitudes. Assessment of attitude aspect is done by teacher where the information obtained through observation of student attitude during learning process take place; 2) Knowledge Assessment. Form of written test and oral test. Written tests consist of objective and non-objective tests. Objective test in the form of multiple choice and essay. Written tests are based on the material of each meeting that must be filled by the students to measure the level of material success of each sub-chapter. The oral test used in this lesson, is a set of questions the teacher reads, which the student must answer verbally; 3) Portfolio Assessment. Portfolio assessment as a form of measurement for a collection of works or files that can provide information. Portfolios in the implementation of this lesson, are contained in duplicate paper that is divided into four sections (problem background, problem solving, alternative policy and action plan). Based on assessments made in assessing the Green Constitution learning model can be classified into summative assessment and formative assessment. Summative assessment is done at the end of the learning process in an attempt to determine students' competence or competence. Formative assessments are conducted to assess student progress at a particular time while still learning to improve learning [14].

Based on the planning of Civic Education based Green Constitution, the learning component description can be described as follows.

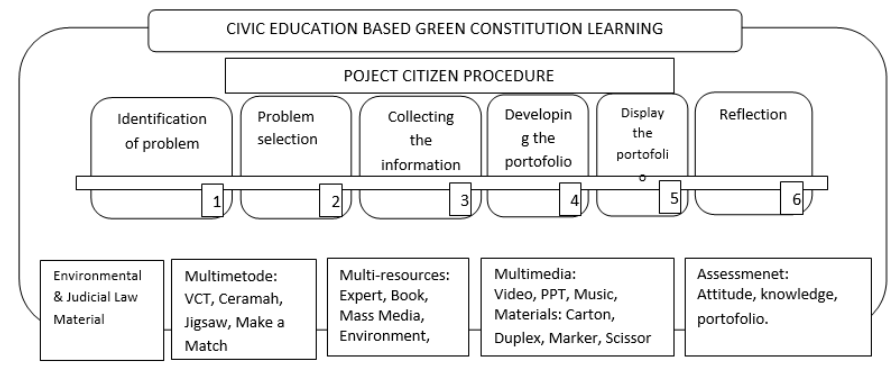

Fig. 2. Innovation Component of Green Constitution Learning Model with Project Citizen

Second, the implementation of Civic Education based Green Constitution learning systematically described from the initial activities, core activities to the closing activities and the values of students' virtue toward the environment are implicitly incorporated. The learning Civic Education based Green Constitution is influenced by constructivist learning theory. The constructivist view suggests that learning is a means of giving meaning to students by experience through assimilation and accommodation leading to the formation of its cognitive structure, enabling it to lead to that goal. Constructivism is a psychological and philosophical perspective which sees that each individual shapes and builds most of what they learn and understand [16,17]. In addition, constructivism theory brings implications in learning that must be collective or group because the success of learning is largely determined by the social roles that exist in students [18]. Therefore, learning is attempted in order to provide the conditions of the formation process optimally in the students themselves.

The implementation of Civic Education based Green Constitution learning model can teach students not only to know about the importance of preserving nature and the environment, but as in Tikson's view students are able to identify problems, solve, make decisions, plan, implement, monitor and evaluate a policy [19]. This is also confirmed by Yuniarto that every citizen is expected not only to have awareness and to participate in the environment, but more importantly every citizen must also have an intelligence in protecting the environment, where ecological intelligence is important as an effort to strengthen against the paradigm of sustainable development [20]. Thus, through this learning was born an innovation in the field of education that became a solution to environmental problems that often occur. Innovation as an attempt to change with the aim of getting a better thing in the field of education [21].

This educational innovation places on a rich learning experience because they not only learn in the classroom, but they also learn outside the classroom, the environment and the place that supports them. Students attempt to combine the knowledge and experience they have with others who are more expert even someone who comes from across disciplines. The three intelligences that are important to produce creativity, including: 1) Synthetic thinking (creative), namely the ability to develop ideas unusual, qualified, and appropriate tasks; 2) Analytical/critical thinking, ie the ability to judge one's ideas, see from strengths and weaknesses, and give suggestions for improvement, and 3) Thinking of practice, i.e. the ability to 
apply intellectual skills in the everyday context and to sell ideas creative [14].

Third, based on the $n$ gain test, the average score for the development of civic virtue of the control class is 0.1223 , meaning that the increase of civic virtue score in the control class has low category. While the average score score obtained in the experimental class of 0.568 , means that the average value of civic virtue in the experimental class has a moderate category. Then it can be seen from the average value of the normalized gain that there is a significant value difference between the experimental class and the control class.

Referring to testing the above hypothesis, it can be seen comparison of control class results and experimental class as shown below:

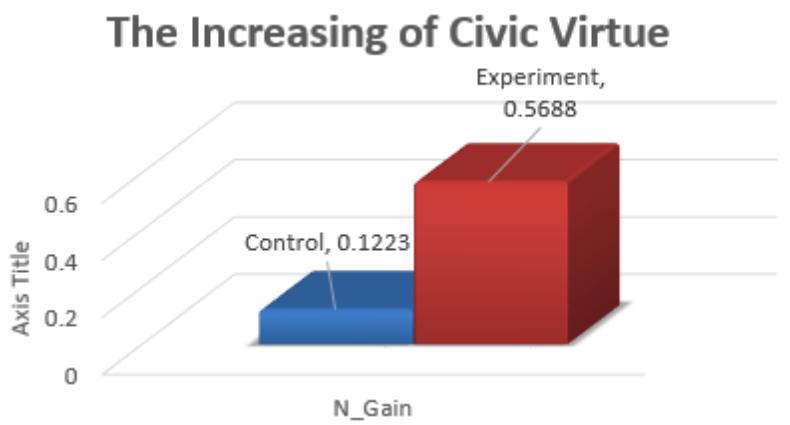

Fig. 3. The Increasing (N Gain) of Civic Virtue in Class Control and Experimental Class

With respect to the standards of students' virtue among control class (classes using conventional learning) with experimental class (classes using green-based Constitutional learning) the experimental class showed better results than the control class. This is reinforced by the community project activities undertaken in the overall form of this Green Constitution learning can inspire the spirit of students through fun learning methods with students' active learning in solving the problems surrounding their environment. It is intended to strengthen the role and interests of students as citizens. The Project Citizen concept is one of the problem-based instructional courses to develop the knowledge, skills and character of democratic citizenship that enable and encourage participation in government and civil society [22].

In addition, this model has a principle of contextual learning that includes: (1) interdependence, this principle leads to the creation of relationships, not isolation; (2) The principle of differentiation, this principle states that everyone is unique, distinct characteristics, diverse socio-cultural background and learning styles; (3) The principle of self-regulation reveals that everything is governed by oneself, defended by oneself, and self-conscious [23,24]. These principles are principles that a citizen must develop if he is to develop a civic virtue within himself.

Thus, this model is assumed to be able to develop the civic virtue both theoretically and practically. Civic virtue is regarded as a dedication of citizens for the welfare of their community groups. The Civic Education based Green Constitution learning invites students closer to the issues that occur in the community and to make alternative policy decisions for every environmental issue. Students are able to have an understanding of citizen participation and civic virtue. Nevertheless, the civic virtue as a citizen will not be of public value if without the understanding of individual freedom and rights [25]. An individual demonstrates the virtues of citizens through voting, volunteering, and organizing welfare groups and meetings. Its duties include: 1) Paying taxes to local and state governments at all times; 2) Maintain a clean and green environment; 3) Does not contaminate water, soil, and air by following proper cleanliness and waste disposal. For example, do not burn wood, tires, plastic materials, spit out in the open, some even smoke in the open, and do not cause disturbance to the community, which become some of the benevolence of citizens, and 4) always follow the rules of road safety [26].

Through the Civic Education based Green Constitution learning, the students as young generation are taught how to be the pioneer of the environment that can give socialization to the people who do not understand about the regulation/policy of environment. In this regard, Civic Education has a role to play in the younger generation, where "Citizenship or civics education is construed broadly to encompass the preparation of young people for their roles and responsibilities as citizens and, in particular, the role of education (through schooling, teaching and learning) in that preparatory process" [27]. This means Civic Education is a process of preparing young people to play a role and be responsible as citizens and in particular the role of education including (through school, teaching and learning) in the preparation process of the citizens.

\section{CONCLUSION}

Civic Education learning process is student learning activities that are engineered by all components of learning that include materials, methods, media, learning resources and evaluation of learning as an important component in learning to take place an effective learning process so as to achieve learning objectives. The purpose of learning is not only focused on one aspect of cognitive but affective aspects and psychomotor aspects need to be instilled in students and behaviors that must be displayed by students. The implementation of Civic Education based Green Constitution lesson systematically illustrated from the initial activity, the core activities to the closing activities and the students' values on the environment are implicitly incorporated. Civic Education based Green Constitution learning is influenced by constructivist learning theory. The constructivist view suggests that learning is a means of giving meaning by students to their experiences through assimilation and accommodation leading to the formation of its cognitive structure, enabling it to lead to the goal of the civilization of student citizenship. Civic Education based Green Constitution learning is an educational innovation to improve the civility of students' virtue, this proves hypothesis that there is an increase between control class (class using conventional learning) with experimental class (class using Civic Education based Green Constitution learning) that the experimental class shows the result better than control class. This is influenced by the activities of the citizen project undertaken in the overall component of Green Constitution-based learning is able to raise the spirit of students 
through fun learning methods with the active involvement of students in solving problems that exist around their environment.

\section{REFERENCES}

[1] Al Gore. Earth in the Balance: Ecology and the Human Spirit. Boston, MA: Houghton Mifflin. 1992.

[2] Kube, R.M. \& Marr, A.G. What can Australian business learn from the United States experience with similar pollution regulations?, paper presented at Pollution Law Conference, Sydney, 5-6 April. 1990,

[3] Winataputra, U. Konsep dan Strategi Pendidikan Moral Pancasila di Sekolah Menengah. Jakarta: P2LPTK Dikti. 1999.

[4] Winataputra. U S. dan Budimansyah. D. Civic Education: Konteks, Landasan, Bahan Ajar, dan Kultur Kelas. Bandung: Prodi PKn SPs UPI. 2007.

[5] Budimansyah, D. Inovasi Pembelajaran Project Citizen. Bandung: Program Studi PKn SPs UPI. 2009.

[6] Creswell, J.W. Research Design: Qualitative and Quantitative Approaches. London \& New Delhi: Sage Publications. 1944.

[7] Borg, W.R., \& Gall, M.G. 1989. Educational Research: An Introduction 5th ed.. New York: Longman.

[8] Asshiddiqie, J. Green Constitution: Nuansa Hijau UUD 1945. Jakarta: Rajawali Pers. 2009.

[9] Djahiri, A. K. Esensi Pendidikan Nilai Moral dan PKn di Era Globalisasi dalam Pendidikan Nilai Moral dalam Esensi Pendidikan Kewarganegaraan. Bandung: Laboratorium Pendidikan Kewarganegaraan FPIPS UPI. 2006.

[10] Ibrahim, Muslimin, dkk.'Pembelajaran Kooperatif". Surabaya : University Press. 2002.

[11] Krathwohl, David. A Revision of Bloom's Taxonomy: An Overview. Theory Into Practice, Volume 41, Number 4, Autumn 2002. 2002.

[12] Turner, et al. Civics: Citizen In Action. United States of America: Merril Publishing Company. 1990.

[13] Crane, Andrew, Dick Marten dan Jeremy Moon. 2008. Ecological Citizenship and the Corporation: Politicizing the New Corporate Environmentalism, journal of SAGE, Volume 21 Number 4
[14] Abdullah, Sani Ridwan. 2014. Pembelajaran Saintifik untuk Kurikulum 2013. Jakarta: Bumi Aksara.

[15] Djamarah dan Aswan Zain. Strategi Belajar Mengajar. Jakarta: Rineka Cipta. 2002.

[16] Brunning RH, Schraw G. J., Norby, MM, \& Ronning, RR. Cognitive psychology and instruction. 2004.

[17] Schunk, Dale H. Teori-teori Pembelajaran: Perspektif Pendidikan. Yogyakarta: Pustaka Pelajar. 2012.

[18] Budiningsih, Asri. Belajar dan Pembelajaran. Jakarta: Rineka Cipta. 2005.

[19] Tikson, D, T. 2009. Partisipasi Masyarakat Dalam Manajemen Perkotaan http://id.shvoong.com/sosial-sciences/politicalsciance/1883653-partisipasi-masyarakat-dalam-manajemen-perkotaan/. Diakses 20 Juni 2009.

[20] Yuniarto, B. 2013. Membangun Kesadaran Warga Negara Dalam Pelestarian Lingkungan. Yogyakarta: Deepublish.

[21] Rahman MN, Udin N, Wahab FA, Ismail R. Innovation management framework in academic institutions. InProceedings of the 9th WSEAS international conference on Applied computer and applied computational science 2010 Apr 11 (pp. 215-220). World Scientific and Engineering Academy and Society (WSEAS).

[22] Budimansyah, D. Penguatan Pendidikan Kewarganegaraan Untuk Membangun Karakter Bangsa. Bandung: Widya Aksara Press. 2010

[23] Johnson Elaine B. Contextual Teaching \& Learning Menjadikan Kegiatan Belajar-Mengajar Mengasyikkan dan Bermakna. Bandung: MLC. 2002.

[24] Komalasari, K. 2012. Pembelajaran Kontekstual: Konsep dan Aplikasi. Bandung: Refika Aditama

[25] Branson MS, Quigley CN. The role of civic education. 1998.

[26] Naagarazan, R.S. 2006. A Textbook On Professional Ethics and Human Values. New Delhi: New Age International. Tersedia: [Online] https://books.google.co.id/books

[27] Kerr, D. Citizenship Education: an International Comparisn, London: National Foundation for Educational Research-NFER. 1999. 